\title{
Analysis of interspecies physicochemical variation of grain legume seeds
}

\author{
Wojciech Rybiński ${ }^{1}$, Robert Rusinek ${ }^{2 *}$, Bogustaw Szot $^{2}$, Jan Bocianowski ${ }^{3}$, and Michat Starzycki ${ }^{4}$ \\ ${ }^{1}$ Institute of Plant Genetics, Polish Academy of Sciences, Strzeszyńska 34, 60-479 Poznań, Poland \\ ${ }^{2}$ Institute of Agrophysics, Polish Academy of Sciences, Doświadczalna 4, 20-290 Lublin, Poland \\ ${ }^{3}$ Department of Mathematical and Statistical Methods, Poznań University of Life Sciences, Wojska Polskiego 28, \\ 60-637 Poznań, Poland \\ ${ }^{4}$ Institute of Plant Breeding and Acclimatization, Department of Oil Plants, Strzeszyńska 36, 60-479 Poznań, Poland
}

Received February 19, 2013; accepted June 11, 2013

\begin{abstract}
A b s t r a c t. The paper presents an attempt to assess the reaction of seeds to mechanical loads taking into account their geometry expressed as seed thickness and 1000 seed weight. The initial material comprised 33 genotypes of grain legume plants and included cultivars registered in the country and breeding lines that are subject to pre-registration trials. The analysis of variance revealed significant diversity of the cultivars and lines of the species studied in terms of each of the analysed trait. The highest weight of 1000 seeds were obtained for white lupine seeds and peas, the lowest for andean lupine seeds. The maximum deformation and energy were obtained for white lupine seeds, the lowest for pea seeds, the maximum force and module the lowest values were determined for narrow-leafed lupine and pea. The highest values of protein were obtained for andean and yellow lupine, a fat content for andean and white lupine. The fatty acid profile as much as $70 \%$ or more were linoleic and oleic acids. Against the background of all the species are distinguished by white lupine seeds with a high content of oleic acid and the lowest of linoleic acid, for yellow lupine were obtained the inverse ratio of the two acids.

K e y w o r d s: grain legumes, seed thickness, static loading of seeds, protein, fat, fatty acids
\end{abstract}

\section{INTRODUCTION}

Grain legume breeders and scientists are very active in promoting their crops and the use of dry seeds as food, the legume green matter as forage, as fresh vegetables, and use in forestry. Of the numerous advantages of this group of crops, the most important benefit ie $\mathrm{N}$-fixation and high protein content, results from a symbiosis with root bacteria (Święcicki et al., 2007). Legumes contribute to reduction of energy costs in agriculture; they are a source of protein in food and feed (Tavoletti et al., 2011) and they contribute to biodiversity in crop rotations and permanent grassland. Some of them are useful for biomass production, land reclamation, or even in forestry. Grain legumes, the subject of the present paper, are highprotein plants. Primarily, they are valuable and one of cheapest sources of protein. About $1.2 \mathrm{mln}$ t of protein per year is needed in Poland for animal fodder, $80 \%$ of which is covered by soybean cake import ( $70 \%$ in Europe). Due to the increasing protein shortage in Poland, it is necessary to import soybean, $90 \%$ of which is constituted by GMO seeds used for animal feeding. The seeds of lupine and pea belong to very cheap and valuables sources of protein. Apart from soybean (42\%), the seeds of lupine are richer in the protein content $(32 \%)$ in comparison with faba bean $(24 \%)$ and pea (23\%).

In the process of plant growing, the breeder pays attention primarily to the values of the main traits connected with the yield potential, quality of yield, and resistance to diseases and pests (Calderon et al., 2012). Other traits are also important, but they are often disregarded by breeders due to lack of necessary equipment or, in many cases, experience. These traits include the mechanical properties of seeds (Grundas, 2004). This element is underestimated and still little known. Knowledge of the physical parameters of seeds has particular importance for optimization of technologies of harvesting, drying and storage, which is related to minimization of quantitative losses and mechanical damage (Rybiński and Szot, 2009). The biological values of seeds, characterized - among other things - by

*Corresponding author e-mail: rrusinek@ipan.lublin.pl 
their germination capacity, is determined by a number of external factors $i e$ beginning with the time of seed ripening under field conditions and ending with the effect of forces acting in harvester threshing assembly, seed cleaning devices, sorting and drying equipment, as well as transport and storage. The technological processes listed above have an effect on the physical status of seeds, which leads to diversification of their resistance to mechanical loads. Micro- and macrodamage formed during those processes may have a negative impact on the quality of seeds and yield. The variability of the physical properties of seeds depends on a great variety of external factors, as well as on species- and cultivar-related traits often connected with the genetic background (Szot and Rybiński, 2011). Expression of these traits depends on different factors during growth and development of plants in the field as well as after harvest. Literature reports indicate the occurrence of notable inter-variety differences in resistance of seeds to mechanical deformation, even at identical geometric parameters of the seeds. This creates a possibility of suitable selection of components for crossbreeding and directed breeding. The knowledge of specific reactions of cultivars or new breeding lines on broadly treated physical properties of seeds could constitute a valuable source of information for a breeder.

With the aim of determining not only the above inter-species but also intra-species differences, an attempt was made at estimating the resistance of seeds to mechanical loads in six species of grain legumes and different cultivars and breeding lines within each species. Additionally, the chemical content of seeds for each form was estimated in terms of the protein and fat content as well as the fatty acid profile.

\section{MATERIALS AND METHODS}

The initial material for the studies consisted of six species of pulse crops cultivated in Poland. Four of them were species of the genus Lupinus: white lupine (Lupinus albus L.), yellow lupine (Lupinus luteus L.), narrowleafed lupine (Lupinus angustifolius L.) and Andean lupine (Lupinus mutabilis Sweet); for comparison with Lupinus, field pea (Pisum sativum L.) and grass pea (Lathyrus sativus L.) were chosen. These six species were represented by seeds of 33 genotypes obtained from the Polish Breeding Station in Przebędowo. One of the most important centres for lupine and field pea breeding in Poland.

Among them, two genotypes represented white lupine (No. 1-Boros, 2-Butan), nine yellow lupine (3-Lord, 4-Mister, 5-Parys, 6-Perkoz, 7-Talar, 8-PRH 714/07, 9-R 851/03, 10-R 867/03, 11-R 1017/03), eleven narrow-leafed lupine (12-Baron, 13-Bojar, 14-Boruta, 15-Graf, 16-Kalif, 17-Mirela, 18-Neptun, 19-Regent, 20-Zeus, 21-PRH 631/08, 22-PRG 1367/08) and three Andean lupine (23Traditional, 24-Determinate, 25-Epigonal). Seven forms constituted cultivars and breeding lines of field pea (26Marych, 27-Medal, 28-Merlin, 29-Milwa, 30-Muza, 31-PRH $145 / 08$, 33-PRH $178 / 08$ and one was the Krab grass pea cultivar (33). Therefore, the commercial cultivars were accompanied by new or older breeding lines, currently tested to be released in the future. The seeds of the cultivars and breeding lines were from the experimental field in Przebędowo in the same harvest year. Growing the plants in the same locality and similar soil-climatic conditions allowed comparison of the results obtained from the cultivars and species.

The seeds were analyzed for their physical properties. The first stage of determination of the geometric properties included only seed thickness due to the more and less spherical shape of seeds typical for all the analyzed forms. This parameter was measured using an adapted dial gauge and an electronic slide caliper with the accuracy of $0.01 \mathrm{~mm}$. To obtain detailed distribution of this property in air-dry seed samples, 30 replications were made.

The resistance of individual seeds to static loading was determined by means of the strength test. The results obtained were used to determine the compressive strength of the seeds. The results of the determination were expressed as the value of four parameters: maximum force $(\mathrm{N})$, maximum deformation (mm), the modulus of elasticity (MPa), and energy (J) (Rusinek et al., 2012).

Harvested seeds of each genotype were used for estimation of the protein and fat content as well as the composition of fatty acids. The protein content was determined by the Kjeldahl method and the percentage fat content by the weight method with fat extraction in the Soxhlet appliance. Chromatography (Hewlett Packard, Gas Chromatograph 5890 ) and the capillary column (30 m, RTX-225) were used for estimation of the composition of fatty acids.

The normality of the distribution of the traits was tested using Shapiro-Wilk normality test (Shapiro and Wilk, 1965). The one-way fixed model of analysis of variance (ANOVA) was carried out to determine the effect of the cultivars on the variability of thickness, force, deformation, energy, and the modulus. The one-way ANOVA was carried out to determine the effect of the species on the variability of the traits. Estimation of the mean values, maximum and minimum values, standard deviation and coefficient of variation was made for the studied traits. The relationships between all the traits were estimated on the basis of correlation coefficients (Kozak et al., 2010). Graphic distribution of the cultivars and lines described by combined traits of seed thickness and mechanical loads was obtained with the use of the analysis of canonical variables (Bocianowski et al., 2012; Morrison, 1976; Rybiński et al., 2009, 2011; Seidler-Łożykowska and Bocianowski, 2012).

\section{RESULTS AND DISCUSSION}

The results of the analysis of variance indicated that the main effects of the cultivars and species were significant for all traits (Table 1). The thickness and 1000 seed weight (TSW) variability ranged from $294 \mathrm{~g}$ for white lupine to $85.9 \mathrm{~g}$ for Andean lupine (Table 2). The TSW values for 
T a b l e 1. Mean squares from the analysis of variance for the investigated traits of chosen cultivars and grain legume lines

\begin{tabular}{|c|c|c|c|c|c|}
\hline \multirow[b]{2}{*}{ Source of variation } & \multicolumn{5}{|c|}{ Parameters } \\
\hline & $\begin{array}{l}\text { Thickness } \\
\text { (mm) }\end{array}$ & $\begin{array}{l}\text { Force max } \\
\text { (N) }\end{array}$ & $\begin{array}{l}\text { Deformation max } \\
(\mathrm{mm})\end{array}$ & $\begin{array}{c}\text { Energy } \\
(\mathrm{J})\end{array}$ & $\begin{array}{c}\text { Modulus } \\
\text { of elasticity } \\
(\mathrm{MPa})\end{array}$ \\
\hline Cultivars & $3.579 * * *$ & $147094 * * *$ & $2.348 * * *$ & $1.470 * * *$ & $58871 * * *$ \\
\hline Residual & 0.026 & 36132 & 0.219 & 0.097 & 9336 \\
\hline Species & $21.035^{* * *}$ & $63278 * * *$ & $13.14 * * *$ & $7.84 * * *$ & $303831 * * *$ \\
\hline Residual & 0.08 & 39592 & 0.24 & 0.13 & 10045 \\
\hline
\end{tabular}

$* * * \mathrm{p}<0.001$.

T a b l e 2. Characteristics of the variation for thousand seed weight, seed thickness and parameters of static loading

\begin{tabular}{|c|c|c|c|c|c|}
\hline $\begin{array}{l}\text { Parameters and } \\
\text { species }\end{array}$ & Mean & Minimum & Maximum & Standard deviation & $\begin{array}{l}\text { Coefficient of } \\
\text { variation }(\%)\end{array}$ \\
\hline \multicolumn{6}{|c|}{ Thousand seed weight (g) } \\
\hline Field pea & 217.84 & 169.2 & 250.4 & 28.86 & 13.25 \\
\hline Grass pea & 176.40 & 176.4 & 176.4 & 0 & 0 \\
\hline Andean lupine & 85.99 & 80.01 & 95.9 & 8.64 & 10.05 \\
\hline White lupine & 294.80 & 253.2 & 336.4 & 58.9 & 20.00 \\
\hline Narrow-leafed lupine & 128.14 & 100.05 & 145.09 & 11.95 & 9.33 \\
\hline Yellow lupine & 125.67 & 113.45 & 149.66 & 12.27 & 9.77 \\
\hline \multicolumn{6}{|c|}{ Seed thickness (mm) } \\
\hline Field pea & 6.432 & 5.942 & 6.998 & 0.31 & 4.84 \\
\hline Grass pea & 4.934 & 4.943 & 4.934 & 0 & 0 \\
\hline Andean lupine & 3.918 & 3.779 & 4.032 & 0.12 & 3.27 \\
\hline White lupine & 4.799 & 4.221 & 5.377 & 0.81 & 17.03 \\
\hline Narrow-leafed lupine & 4.858 & 4.617 & 5.136 & 0.17 & 3.55 \\
\hline Yellow lupine & 4.435 & 4.226 & 4.766 & 0.19 & 4.32 \\
\hline \multicolumn{6}{|c|}{ Force max. $(\mathrm{N})$} \\
\hline Field pea & 354.5 & 307.4 & 426.9 & 41.8 & 11.8 \\
\hline Grass pea & 299.1 & 299.1 & 299.1 & 0 & 0 \\
\hline Andean lupine & 323.5 & 218.9 & 465.9 & 127.8 & 39.5 \\
\hline White lupine & 180.25 & 165.5 & 194.9 & 20.72 & 11.49 \\
\hline Narrow-leafed lupine & 624.2 & 406.2 & 919.6 & 128.8 & 20.6 \\
\hline Yellow lupine & 517.6 & 413.6 & 796.1 & 109.3 & 21.1 \\
\hline
\end{tabular}


T a b l e 2. Continuation

\begin{tabular}{|c|c|c|c|c|c|}
\hline $\begin{array}{l}\text { Parameters and } \\
\text { species }\end{array}$ & Mean & Minimum & Maximum & Standard deviation & $\begin{array}{l}\text { Coefficient of } \\
\text { variation (\%) }\end{array}$ \\
\hline \multicolumn{6}{|c|}{ Deformation max. (mm) } \\
\hline Field pea & 0.582 & 0.472 & 0.753 & 0.096 & 16.25 \\
\hline Grass pea & 0.606 & 0.606 & 0.606 & 0 & 0 \\
\hline Andean lupine & 1.631 & 1.354 & 2.036 & 0.35 & 21.96 \\
\hline White lupine & 2.464 & 1.842 & 3.086 & 0.88 & 35.7 \\
\hline Narrow-leafed lupine & 2.155 & 1.856 & 2.678 & 0.25 & 11.65 \\
\hline Yellow lupine & 1.637 & 1.37 & 1.799 & 0.14 & 9.03 \\
\hline \multicolumn{6}{|c|}{ Energy $(\mathrm{J})$} \\
\hline Field pea & 0.104 & 0.068 & 0.166 & 0.03 & 34.22 \\
\hline Grass pea & 0.091 & 0.091 & 0.0911 & 0 & 0 \\
\hline Andean lupine & 0.51 & 0.21 & 0.88 & 0.34 & 66.74 \\
\hline White lupine & 2.223 & 1.585 & 2.862 & 0.90 & 40.62 \\
\hline Narrow-leafed lupine & 0.816 & 0.53 & 1.159 & 0.20 & 24.80 \\
\hline Yellow lupine & 0.514 & 0.322 & 0.723 & 0.11 & 21.51 \\
\hline \multicolumn{6}{|c|}{ Modulus of elasticity (MPa) } \\
\hline Field pea & 490.2 & 404.3 & 614.4 & 83 & 16.9 \\
\hline Grass pea & 473.8 & 473.8 & 473.8 & 0 & 0 \\
\hline Andean lupine & 151.1 & 131.4 & 187.7 & 31.73 & 21 \\
\hline White lupine & 339.6 & 264.2 & 414.9 & 106.6 & 31.4 \\
\hline Narrow-leafed lupine & 295.7 & 251.3 & 365.7 & 36.9 & 12.5 \\
\hline Yellow lupine & 347 & 319.8 & 369.3 & 24 & 6.9 \\
\hline
\end{tabular}

yellow (125 g) and narrow-leafed lupine (128 g) were similar, whereas higher values were characteristic for grass pea (176 g), and particularly field pea (217 g). The lowest value was estimated for Andean lupine. In the study of SawickaSienkiewicz and Galek (2003), the TSW variability range for Andean lupine mutants exhibited a higher level than that demonstrated in the present paper and it was between 108 and $164 \mathrm{~g}$; the mean value for yellow lupine was $139.7 \mathrm{~g}$ (Paszkiewicz, 2007) and that for grass pea $193 \mathrm{~g}$ (Milczak et al., 2001). A trait that is significantly correlated with the mechanical load parameters is seed thickness (Table 2). Among the assessed species, the field pea seeds exhibited the highest mean thickness of $6.4 \mathrm{~mm}$ and a narrow variability range of 5.9 to $6.9 \mathrm{~mm}$. The second group of species characterised by lower thickness than that of field pea comprised white, yellow and narrow-leafed lupine, and grass pea, with the mean values from $4.4 \mathrm{~mm}$ for the yellow lupine forms to $4.9 \mathrm{~mm}$ for grass pea. The lowest values were reported for the Andean lupine species; they ranged from 3.77 for the determinate form to $4.0 \mathrm{~mm}$ for the traditional form. The highest variability of seed thickness expressed by the coefficient of variation was found in the white lupine genotypes (17.03\%), whereas the cultivars and lines of Andean, narrow-leafed, yellow lupines and pea displayed a lower level (from 3.27 to $4.84 \%$ ) (Table 2).

To meet the requirements of modern economy, crop plant cultivars should yield plants material and a biological product that will satisfy the demand and standards and simultaneously reduce possible losses (Rybiński and Szot 2009; Szot and Rybiński, 2011). Therefore, knowledge of the physical traits (Grundas, 2004) of the biological material from various crop species is indispensable to assess its quality (Szot et al., 2005). The values of the mechanical load parameters in the seeds of the individual species 
are presented in Table 2. In terms of maximum force $(\mathrm{N})$, the highest mean value was obtained for the cultivars of narrow-leafed lupine $(624 \mathrm{~N})$ with the widest minimummaximum measurement range from 406.2 to $919.6 \mathrm{~N}$, and for the yellow lupine cultivars $(517.6 \mathrm{~N}$; the range from 413 to $796 \mathrm{~N}$ ). Lower and similar values were obtained for field pea $(354.5 \mathrm{~N})$, Andean lupine (323.5 N), and grass pea $(299.1 \mathrm{~N})$. Compared with these species, the white lupine cultivars exhibit the lowest mean value of maximum force $(180.2 \mathrm{~N})$. According to literature data, the mean value of maximum force for grass pea is $299.1 \mathrm{~N}$, or in other reports 279 and 257 N (Szot et al., 1998). Values that were lower than those reported for grass pea, lupines, and field pea were obtained for two lentil cultivars Anita $(179.2 \mathrm{~N})$ and Tina, (160.1 N) (Szot and Stępniewski, 2000). In comparison, resistance to mechanical loads in caryopses of spring barley cultivars and mutants ranged between 107 and $227 \mathrm{~N}$. The other mechanical load parameter analysed was the maximum deformation. The mean value of this parameter was from $0.582 \mathrm{~mm}$ for the grass pea to $2.464 \mathrm{~mm}$ for the white lupine cultivars (Table 2). A similar value to that for white lupine was found in the narrow-leafed lupine seeds $(2.155$ $\mathrm{mm})$. The highest coefficient of variation was calculated for the white lupine forms $(35.7 \%)$, while the lowest for the yellow lupine cultivars $(9.03 \%)$. The maximum deformation value for the grass pea $c v$. Krab was $0.606 \mathrm{~mm}$. In a study of European forms of grass pea, this value was reported to reach $0.440 \mathrm{~mm}$ (Rybiński et al., 2008), which was slightly lower than that presented in this paper. According to other authors (Szot et al., 1998), the maximum deformation values for the Krab and Derek cultivars were 0.41 and $0.35 \mathrm{~mm}$, and 0.40 and $0.26 \mathrm{~mm}$ for the Anita and Tina lentil cultivars (Szot and Stępniewski, 2000). Resistance to compression measured with the amount of energy exhibited high variability depending on the genotype. The mean value of this parameter in the initial form ranged between $0.091 \mathrm{~J}$ for grass pea and $2.22 \mathrm{~J}$ for the white lupine cultivars (Table 2). Similar values were characteristic for the morphologically and genetically similar grass pea and field pea $(0.09$ and $0.10 \mathrm{~J})$, and in the other group - for the narrowleafed and yellow lupine $(0.81$ and $0.51 \mathrm{~J})$. In terms of this trait, the cultivars of white and Andean lupine, especially its epigonal form, are particularly distinct. The final mechanical load parameter estimated was the value of the modulus of elasticity. The highest mean values (over $400 \mathrm{MPa}$ ) were recorded for the field pea and grass pea seeds; the yellow and white lupine cultivars were characterized by values exceeding $300 \mathrm{MPa}$, and the lowest values (295 and $151 \mathrm{MPa}$ ) were exhibited by the seeds of narrow-leafed and Andean lupine (Table 2). The highest values of the coefficient of variation were recorded for white lupine, next for field pea, followed by the cultivars and lines of narrow-leafed, Andean, and yellow lupine.

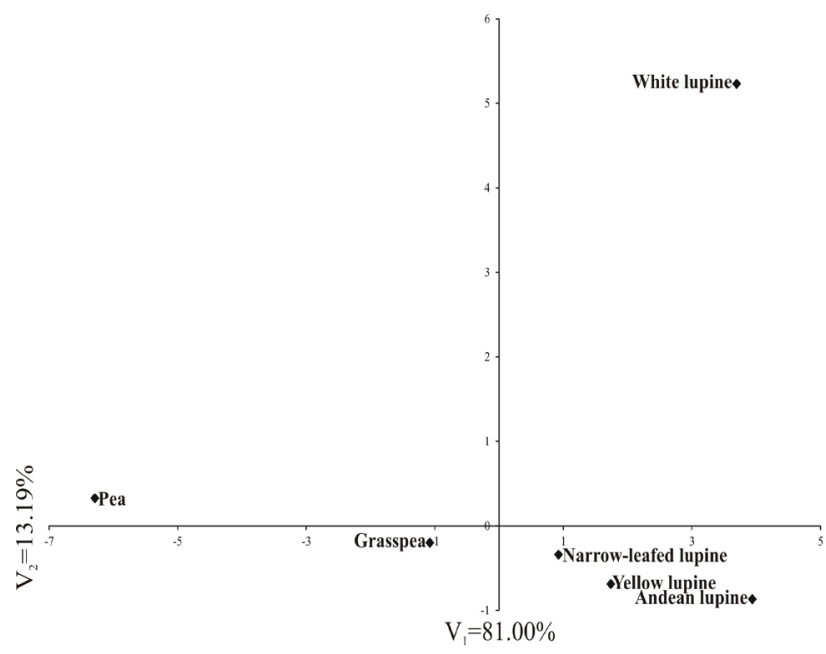

Fig. 1. Distribution of species in the space of two first canonical variables for seed thickness combined with mechanical load parameters.

Figure 1 shows the distribution of the cultivars and lines of the tested species in the system of the first two canonical variables for seed thickness combined with the four mechanical load parameters. Three clusters can be distinguished. The first one (at the top of the figure), which is the most distinct, consists of the white lupine cultivars. The second cluster (on the left side of the figure) is constituted by the field pea cultivars, and the third is formed by the rightmost Andean lupine, closely located cultivars and lines of yellow and narrow-leafed lupine, and grass pea situated further towards the field pea cultivars. In summary, it can be claimed that the greatest differences in terms of the mechanical load parameters ware exhibited by the white lupine and field pea seeds. The large differences in the reaction of white lupine seeds to the impact of external mechanical loads may be related to their different internal structure. Analyses of the seed microstructure may elucidate, at least to some extent, the observed differences.

In order to estimate the relationships among the TSW, seed thickness, and mechanical load parameters, the correlation coefficients were calculated (Table 3 ). Statistically significant values were obtained for most traits. Seed thickness was correlated positively and significantly with the TSW and modulus of elasticity, and significantly and negatively correlated with the maximum deformation. Furthermore, negative correlation between seed thickness and the maximum forced was not statistically significant. In turn, the TSW was correlated positively and significantly with the thickness and modulus, and negatively correlated with the maximum force. Among the four parameters of mechanical load, the modulus was correlated significantly and negatively with the maximum deformation and energy, and the 
T a b l e 3. Coefficients of correlation for seed thickness, thousand seed weight (TSW) and mechanical load parameters

\begin{tabular}{|c|c|c|c|c|c|c|}
\hline Parameter & $\begin{array}{l}\text { Thickness } \\
(\mathrm{mm})\end{array}$ & $\begin{array}{l}\text { Modulus } \\
\text { of elasticity } \\
(\mathrm{MPa})\end{array}$ & $\begin{array}{l}\text { Force max } \\
\text { (N) }\end{array}$ & $\begin{array}{c}\text { Deformation } \\
\max (\mathrm{mm})\end{array}$ & $\begin{array}{c}\text { Energy } \\
(\mathrm{J})\end{array}$ & TSW \\
\hline Modulus of elasticity & $0.747 * * *$ & 1 & & & & \\
\hline Force max & -0.219 & -0.138 & 1 & & & \\
\hline Deformation max & $-0.594 * * *$ & $-0.646^{* * *}$ & $0.486^{* *}$ & 1 & & \\
\hline Energy & -0.297 & $-0.389 *$ & 0.060 & $0.787 * * *$ & 1 & \\
\hline TSW & $0.700 * * *$ & $0.591 * * *$ & $-0.492 * *$ & -0.273 & 0.257 & 1 \\
\hline
\end{tabular}

${ }^{*} \mathrm{p}<0.05, * * \mathrm{p}<0.01, * * * \mathrm{p}<0.001$

maximum force had a significant and positive correlation with the maximum deformation only. Moreover, a high significant correlation between energy and the maximum deformation as well as a significant negative correlation between energy and the modulus value were calculated. The only parameter of mechanical loads that exhibited statistically significant correlations with the other three parameters was the maximum deformation. This parameter was positively correlated with the maximum force and energy, and negatively with the modulus of elasticity.

In the present study, two species ie Andean and yellow lupine had the highest protein content ie 41.2 and 39.3\%, respectively (Table 4). According to Sawicka-Sienkiewicz and Galek (2003), the protein content exceeding $40 \%$ is the most important performance trait in Andean lupine. In turn, the high protein content in yellow lupine seeds was confirmed by the results obtained by Wiatr and Dolata (2007), who reported values in the range of $42.5-44.6 \%$ for nine cultivars and 43-45.1\% for ten cultivars (Paszkiewicz, 2007). The group with a lower protein content comprised white $(31.8 \%)$ and narrow-leafed lupine (28.0\%). According to other authors, the protein content in seeds of three white lupine cultivars ranged from 33.4 to $36.1 \%$ (Wiatr and Dolata, 2007), from 29.2 to $33.0 \%$ in 13 cultivars of narrow-leafed lupine (Stawiński, 2010), and from 30.7 to $33.9 \%$ in eleven lupine cultivars. The third group was characterized by the lowest protein content and comprised grass pea $(25 \%)$ and field pea $(22.9 \%)$.

The highest fat content was found in the Andean lupine seeds with the mean level of $14.8 \%$ (Table 4) and the variability range from $14.2 \%$ in the traditional to $15.6 \%$ in the determinate forms. The fat content in the Andean lupine seeds was found to be $14 \%$ and even $21 \%$ in some selected forms (Hardy et al., 1998; Niwińska and SawickaSienkiewicz, 1999 ). The second highest content of fat was found in white lupine with the mean value reaching $10.9 \%$. Three cultivars of white lupine exhibited a fat content within the range of 10.0-12.1\% (Wiatr and Dolata, 2007). The mean fat content in the narrow-leafed lupine seeds was $6.5 \%$; it was only slightly higher than that in the yellow lupine seeds ie $5.7 \%$; the variability range was $5.69-7.76 \%$ and 4.86-8.76\%, respectively. Both field pea and grass pea seeds were characterized by a distinctly lower fat content, compared with lupines, with a mean value of 1.57 (pea) and $1.05 \%$ (grasspea). Similar values of 1.7 and $1.3 \%$ for field pea were reported by Hanbury et al. (2000).

Regardless of the species, oleic and linoleic acids dominated in the fatty acid profiles (Table 4). The mean content of both acids ranged from $30.1 \%$ for yellow lupine to $61.65 \%$ for white lupine, and from $15.6 \%$ for white lupine to $40.54 \%$ for narrow-leafed lupine, respectively. Interestingly, yellow lupine is the only species whose seeds contain more linoleic than oleic acid (30\% of oleic acid and as much as $51.9 \%$ of linoleic acid). In turn, two species ie grass pea and narrow-leafed lupine, are characterised by the same proportion of both oleic and linoleic fatty acids. As reported by Caligari et al. (2000), Andean lupine seeds are rich in unsaturated fatty acids, particularly in linolenic acid, and the oil has a light-yellow colour and a pleasant taste. According to Hanbury et al. (2000), the fatty acid profile in grass pea is similar in most to that in the seeds of other grain legumes, with the highest content of oleic acids (58.3) and linoleic (14.1). The high content of polyunsaturated fatty acids has an impact on the nutritional value of fat. The investigations conducted by Hanbury et al. (2000) demonstrate predominance of oleic and linoleic acids in the fat of pea. The second group of fatty acids in terms of their high content in fat comprises unsaturated linolenic acid and saturated palmitic acid, from $2.8 \%$ for Andean lupine to $12.7 \%$ for field pea and from $4.7 \%$ for yellow lupine to $11.8 \%$ for Andean lupine, respectively. Compared with all the species, the field pea cultivars exhibited a different content of linoleic acid, and the seeds of Andean and narrowed-leafed lupine had a distinctly different content of palmitic acid. The highest content of saturated stearic acid was found in the seeds of Andean (5.6\%) and narrow-leafed $(5.3 \%)$ lupine, and the lowest content was characteristic for the white lupine seeds (2\%). In turn, compared with all the species, the white lupine seeds displayed a high content of eicosenoic acid, which reached $4.65 \%$. Trace amounts of 
T a b l e 4. Characteristics of the variation of the seed chemical composition

\begin{tabular}{|c|c|c|c|c|c|}
\hline Traits and species & $\begin{array}{l}\text { Mean } \\
(\%)\end{array}$ & $\begin{array}{c}\text { Minimum } \\
(\%)\end{array}$ & $\begin{array}{c}\text { Maximum } \\
(\%)\end{array}$ & Standard deviation & $\begin{array}{l}\text { Coefficient of } \\
\text { variation (\%) }\end{array}$ \\
\hline \multicolumn{6}{|c|}{ Protein } \\
\hline Field pea & 22.8 & 20.68 & 26.35 & 2.07 & 9.06 \\
\hline Grass pea & 24.96 & 24.96 & 24.96 & 0 & 0 \\
\hline Andean lupine & 41.22 & 38.08 & 44.2 & 3.06 & 7.43 \\
\hline White lupine & 31.77 & 30.94 & 32.61 & 1.18 & 3.72 \\
\hline Narrow-leafed lupine & 28.03 & 23.74 & 32.29 & 3.14 & 11.19 \\
\hline Yellow lupine & 39.26 & 32.69 & 45.61 & 3.75 & 9.56 \\
\hline \multicolumn{6}{|c|}{ Fat } \\
\hline Field pea & 1.579 & 1.43 & 1.91 & 0.184 & 11.68 \\
\hline Grass pea & 1.05 & 1.05 & 1.05 & 0 & 0 \\
\hline Andean lupine & 14.81 & 14.12 & 15.56 & 0.721 & 4.86 \\
\hline White lupine & 10.92 & 9.76 & 12.9 & 1.648 & 15.08 \\
\hline Narrow-leafed lupine & 6.56 & 5.69 & 7.76 & 0.718 & 10.94 \\
\hline Yellow lupine & 5.69 & 4.86 & 8.76 & 1.22 & 21.40 \\
\hline \multicolumn{6}{|c|}{ Palmitic acid $\left(\mathrm{C}_{16: 0}\right)$} \\
\hline Field pea & 7.25 & 6.3 & 8.1 & 0.75 & 10.33 \\
\hline Grass pea & 6.7 & 6.7 & 6.7 & 0 & 0 \\
\hline Andean lupine & 11.84 & 11.8 & 11.9 & 0.058 & 0.48 \\
\hline White lupine & 6.2 & 5.9 & 6.5 & 0.424 & 6.84 \\
\hline Narrow-leafed lupine & 10.03 & 8.8 & 11.7 & 0.88 & 8.76 \\
\hline Yellow lupine & 4.72 & 4 & 5.1 & 0.342 & 7.24 \\
\hline \multicolumn{6}{|c|}{ Stearic acid $\left(\mathrm{C}_{18: 0}\right)$} \\
\hline Field pea & 2.98 & 2.3 & 3.5 & 0.471 & 15.76 \\
\hline Grass pea & 3.4 & 3.4 & 3.4 & 0 & 0 \\
\hline Andean lupine & 5.66 & 5.0 & 6. & 0.651 & 11.48 \\
\hline White lupine & 2.0 & 1.6 & 2.4 & 0.566 & 28.28 \\
\hline Narrow-leafed lupine & 5.33 & 4.4 & 6.8 & 0.768 & 14.40 \\
\hline Yellow lupine & 2.34 & 2.0 & 3.1 & 0.347 & 14.79 \\
\hline
\end{tabular}


T a b l e 4. Continuation

\begin{tabular}{|c|c|c|c|c|c|}
\hline Traits and species & Mean $(\%)$ & Minimum (\%) & Maximum (\%) & Standard deviation & Coefficient of variation (\%) \\
\hline \multicolumn{6}{|c|}{ Oleic acid $\left(\mathrm{C}_{18: 1}\right)$} \\
\hline Field pea & 40.29 & 37.0 & 46.5 & 3.41 & 8.47 \\
\hline Grass pea & 41.0 & 41.0 & 41.0 & 0 & 0 \\
\hline Andean lupine & 44.93 & 43.4 & 46.3 & 1.46 & 3.24 \\
\hline White lupine & 61.55 & 60.9 & 62.4 & 1.06 & 1.72 \\
\hline Narrow-leafed lupine & 39.01 & 36.3 & 41.5 & 1.45 & 3.73 \\
\hline Yellow lupine & 30.12 & 27.1 & 33.8 & 2.3 & 7.64 \\
\hline \multicolumn{6}{|c|}{ Linoleic acid $\left(\mathrm{C}_{18: 2}\right)$} \\
\hline Field pea & 36.51 & 31.7 & 39.7 & 3.11 & 8.51 \\
\hline Grass pea & 39.7 & 39.7 & 39.7 & 0 & 0 \\
\hline Andean lupine & 34.47 & 33.2 & 35.2 & 1.1 & 3.2 \\
\hline White lupine & 15.6 & 14.5 & 16.7 & 1.556 & 9.97 \\
\hline Narrow-leafed lupine & 40.54 & 38.5 & 43.4 & 1.47 & 3.63 \\
\hline Yellow lupine & 51.93 & 47.2 & 55.3 & 2.24 & 4.31 \\
\hline \multicolumn{6}{|c|}{ Linolenic acid $\left(\mathrm{C}_{18: 3}\right)$} \\
\hline Field pea & 12.71 & 11.8 & 13.8 & 0.623 & 4.9 \\
\hline Grass pea & 9.2 & 9.2 & 9.2 & 0 & 0 \\
\hline Andean lupine & 2.86 & 2.8 & 2.9 & 0.058 & 2.01 \\
\hline White lupine & 8.15 & 8.0 & 8.3 & 0.212 & 2.60 \\
\hline Narrow-leafed lupine & 4.90 & 3.9 & 5.7 & 0.599 & 12.20 \\
\hline Yellow lupine & 8.13 & 6.7 & 9.8 & 1.085 & 13.34 \\
\hline \multicolumn{6}{|c|}{ Eicosenoic acid $\left(\mathrm{C}_{20: 1}\right)$} \\
\hline Field pea & 0.23 & 0 & 0.9 & 0.39 & 172.64 \\
\hline Grass pea & 0 & 0 & 0 & 0 & $*$ \\
\hline Andean lupine & 0.2 & 0.2 & 0.2 & 0 & 0 \\
\hline White lupine & 4.65 & 4.3 & 5.0 & 0.495 & 10.64 \\
\hline Narrow-leafed lupine & 0.21 & 0 & 0.4 & 0.2 & 96.73 \\
\hline Yellow lupine & 2.02 & 1.8 & 2.3 & 0.156 & 7.73 \\
\hline \multicolumn{6}{|c|}{ Erucic acid $\left(\mathrm{C}_{22: 1}\right)$} \\
\hline Field pea & 0 & 0 & 0 & 0 & $*$ \\
\hline Grass pea & 0 & 0 & 0 & 0 & $*$ \\
\hline Andean lupine & 0 & 0 & 0 & 0 & $*$ \\
\hline White lupine & 1.75 & 1.7 & 1.8 & 0.071 & 4.041 \\
\hline Narrow-leafed lupine & 0 & 0 & 0 & 0 & $*$ \\
\hline Yellow lupine & 0.722 & 0.5 & 1.0 & 0.164 & 22.728 \\
\hline
\end{tabular}




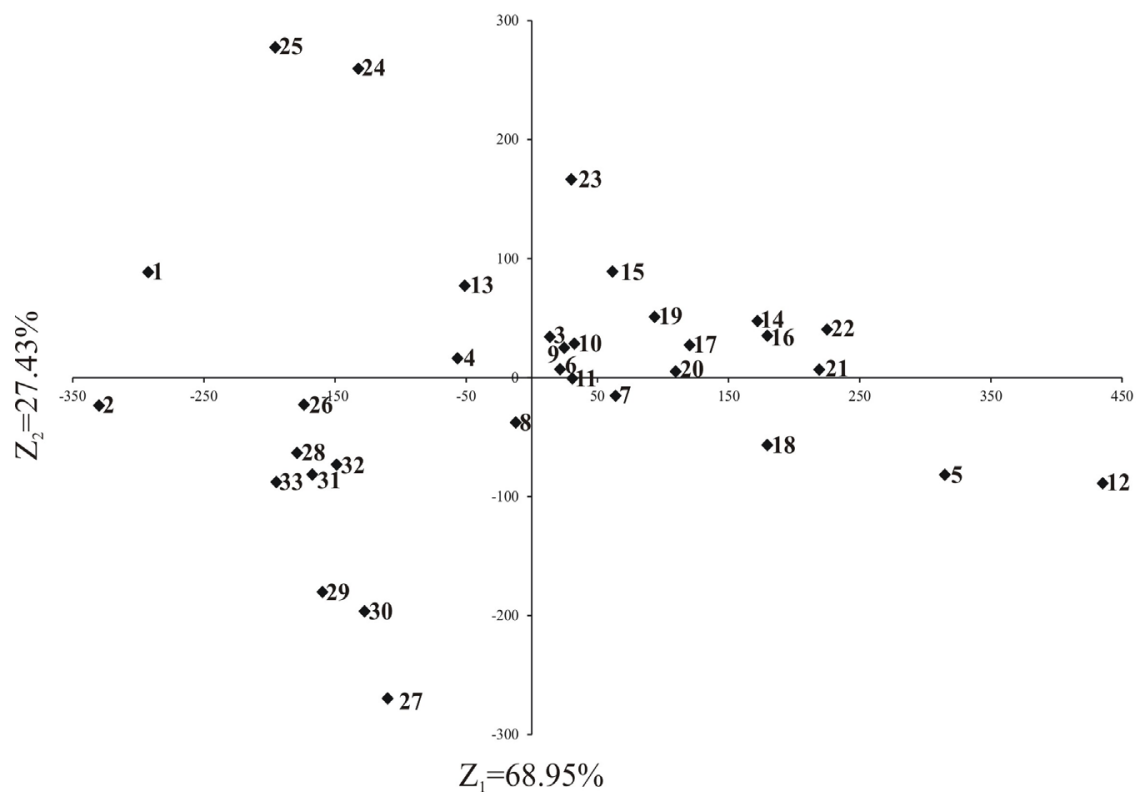

Fig. 2. Distribution of cultivars and lines in the space of two principal components for all analysed traits together (thousand seed weight, seed thickness, mechanical loads and chemical composition of seeds). The meaning of the abbreviations is given in the 'Material and Methods' chapter.

erucic acid were detected only in the white lupine seeds. The highly favourable composition of the fatty acid profile is evidenced by the low content of saturated (stearic and palmitic) fatty acids, consumption of which increases cholesterol levels. Importantly, the high content of oleic acid ie a monounsaturated acid non-synthesized by the human organism, is particularly noteworthy, as it reduces blood levels of LDL cholesterol and has a protective role in prophylaxis of atherosclerosis. Attention should also be paid to the high content of polyunsaturated acids ie linolenic acid, and particularly, linoleic acid, which are regarded as essential fatty acids (Wałkowski et al., 2008).

To summarize the diversity of all the traits (TSW, seed thickness, mechanical load parameters, and chemical composition) of the cultivars and breeding lines, spatial distribution of the results obtained is presented in Fig. 2. Three basic clusters of cultivars and lines can be distinguished. The first cluster on the extreme left of the plane consists of the white lupine cultivars (1 and 2); the second cluster, below the white lupine cultivars, contains the field pea cultivars (26-32) and the botanically and morphologically similar grass pea cultivar (33). The third cluster in the central part of the plane is formed by the cultivars and lines of the other lupine species, with certain separateness of Andean lupine (23-25) and significant similarity of yellow (3-11) and narrow-leafed lupine (12-22). This indicates not only the intra-species diversity of the cultivars and lines tested in terms of all the traits studied, but also interspecies differences between the lupine and pea species. The clusters also demonstrate considerable separateness of white lupine, followed by the Andean lupine species as well as considerable similarity between yellow and narrow-leafed lupines. These genetically based differences may contribute to further breeding and genetic work aimed at improvement of grain legume traits.

\section{CONCLUSIONS}

1. The mean square values obtained from the analysis of variance demonstrate significant diversity in the seed thickness and mechanical load parameters among the cultivars and lines of the tested species.

2. The analysis of the distribution of the cultivars in the system of the first two canonical variables of combined seed thickness and mechanical load parameters demonstrated the highest species separateness of the white lupine seeds. Another separate group consisted of the field pea cultivars and lines, and the third group was formed by grass pea and narrowed-leafed, yellow, and Andean lupine.

3. Irrespective of the species, oleic acid and linoleic acid were predominant in the fatty acid profile. The yellow lupine is noteworthy as only its seeds contained more linoleic than oleic acid. Compared with all the species, the field pea cultivars were distinguished by a remarkable content of linolenic acid, while the Andean and narrow-leafed lupine seeds had considerable amounts of palmitic acid.

4. The results may be usefull for plant breeders pointing differences of seeds in response to their mechanical loads and be an important contributory factor to the selection of seeds collections with improved resistance to crushing and their use as a starting material in the breeding work on improving legumes. 


\section{REFERENCES}

Bocianowski J., Joachimiak K., and Wójciak, A., 2012. The influence of process variables on the strength properties of NSSC birch pulp. Towards the limits of optimization: part one - the effect of liquor ratio. Drewno, 188, 17-32.

Calderon F.J., Vigil M.F., Nielsen D.C., Benjamin J.G., and Poss D.J., 2012. Water use and yields of no-till managed dryland grasspea and yellow pea under diffrent planting configurations. Field Corps Res., 125, 179-185.

Caligari P.D.S., Rahim M.A., Roemer P., Huyghe C., Neves Martins J., and Sawicka-Sienkiewicz E.J. 2000. The potential of Lupinus mutabilis as a crop. In: Linking Research and Marketing Opportunites for Pulses in 21st Century (Ed. K. Knigh). Kluwer Academic Press.

Grundas S., 2004. Characteristics of physical properties of single kernels along length of heads in common wheat (Triticum aestivum L.) (in Polish). Acta Agrophysica, 102, 1-64.

Hanbury C.D., White C.L., Mullan B.P, and Siddique K.H.M., 2000. A review of the potential of Lathyrus sativus L. and $L$. cicera L. grain for use as animal feed. Anim. Feed Sci. Tech., 87, 1-27.

Hardy A., Huyghe C., Rahim M.A., Roemer P, Neves Martins J.M., and Sawicka Sienkiewicz E., 1998. Effect of genotype and environment on architecture and flowering time on indetermine Andean lupins (Lupinus mutabilis Sweet). Aust. J. Agric. Res., 49, 1241-1251.

Kozak M., Bocianowski J., Sawkojć S., and Wnuk A., 2010. Call for more graphical elements in statistical teaching and consultancy. Biometrical Letters, 47(1), 57-68.

Milczak M., Pedzinski M., Mnichowska H., Szwed-Urbas K., and Rybiński W., 2001. Creative breeding of grasspea (Lathyrus sativus L.) in Poland. Lathyrus Lathyrism Newsl., 2, 85-89.

Morrison D.F., 1976. Multivariate statistical methods. Mc GrawHill Kogakusha, Tokio, Japan.

Niwińska B. and Sawicka-Sienkiewicz E.J., 1996. The chemical composition and nutritive value of Lupinus mutabilis sweet for rats. Proc. 8th Int. Lupin. Conf., May 11-16, Davis, CA, USA.

Paszkiewicz Z., 2007. Cultivation of White Lupine (in Polish). BiznesAgroSerwis Press, Warsaw, Poland.

Rusinek R., Rybczyński R., Tys J., Gawrysiak-Witulska M., Nogala-Kalucka M., and Siger A., 2012. The proces for non-typical seeds during simulated cold deep oil expression. Czech J. Food Sci., 30(2), 126-134.

Rybiński W. and Szot B., 2009. Relations between agrophysics and genetics and breeding of cereals and legumes (in Polish). Acta Agrophysica, 174, 1-55.

Rybiński W., Szot B., Bocianowski J., and Rusinek R., 2011. Geometric properties of grasspea seeds and their mechanical loads. Int. Agrophys., 25, 271-280.
Rybiński W., Szot B., and Rusinek R., 2008. Estimation of morphological and mechanical properties of grasspea seeds (Lathyrus sativus L.) originating from EU countries. Int. Agrophysics, 22, 261-275.

Rybiński W., Szot B., Rusinek R., and Bocianowski J., 2009. Estimation of geometric and mechanical properties of seeds of Polish cultivars and lines representing selected species of pulse crops. International Agrophysics, 23, 257-267.

Sawicka-Sienkiwicz E. and Galek R., 2003. Elements of seed field structure and selected morphological characters of mutants of Andean lupine (L. mutabilis Sweet) in the year 2001. (in Polish), Biul. IHAR, 226/227/2, 497-502.

Seidler-Lożykowska K., and Bocianowski J., 2012. Evaluation of variability of morphological traits of selected caraway (Carum carvi L.) genotypes. Industrial Crops and Products, 35, 140-145.

Shapiro S.S. and Wilk M.B., 1965. An analysis of variance test for normality (complete samples). Biometrika, 52, 591-611.

Stawiński S., 2010. Lupinus angustofolius - species with broad possibilities of use (in Polish). AgroSerwis Press., Warsaw, Poland.

Święcicki W., Chudy M., and Żuk-Gołaszewska K., 2007. Grain legumes in the EU framework programmes (in Polish). Zesz. Probl. Postępów Nauk Roln., 522, 54-65.

Szot B., Milczak M., and Wąsik A., 1998. Characteristics of the physical properties everlasting pea (Lathyrus sativus L.). (in Polish). Conf. Sci. Legumes Protein Plants, December 4, Lublin, Poland.

Szot B. and Rybiński W., 2011. Plant Physical Characteristics in Breeding and Varietal Evaluation. In: Encyclopedia of Agrophysics (Eds J. Glinski, J. Horabik, J. Lipiec). Springer Press, Dordrecht-Heidelberg-London- New York.

Szot B. and Stępniewski A., 2000. Mechanical properties of single kernels of Polish cultivars of lentil (in Polish). Proc. II PTA Conf., September 11-12, Lublin, Dąbrowica, Poland.

Szot B., Stępniewski A., and Rudko T., 2005. Agrophysical properties of lentil (Lens culinaris Medik.) (in Polish). Institute of Agrophysics PAS Press, Lublin, Poland.

Tavoletti S., Iommarini L., and Mogliani L., 2011. Agronomic, qualitative (b-ODAP) and molecular variability in grasspea populations of the Marche region (central Italy). Food Chemical Toxicol., 49, 601-606.

Wałkowski T., Bartkowiak-Broda I., and Krzymański J., 2008. Winter Raps (in Polish). IHAR Press., Radzików, Poland.

Wiatr K. and Dolata A., 2007. Cultivation of sowing pea - the Polish tradition (in Polish). BiznesAgroSerwis Press, Warsaw, Poland. 